\title{
Retrospective and experiential perception of physical activity during pregnancy on childbirth and postpartum period
}

\author{
Marjana Božičl, Ksenija Kragelj', Mirko Prosen' \\ ' University of Primorska, Faculty of Health Sciences, Department of Nursing, \\ Polje 42, 6310 Izola, Slovenia \\ ${ }^{2}$ Community Health Centre Tolmin, Prešernova 6/a, 5220 Tolmin, Slovenia \\ bozic.marjanca@gmail.com; kkragelj@gmail.com; mirko.prosen@fvz.upr.si
}

\section{Abstract}

Introduction: The purpose of the research was to examine the beliefs and experiences of women in the postpartum period on how the physical activity during pregnancy affects the psychological and physical wellbeing, the outcome of childbirth and the recovery in postpartum period. Methods: The qualitative methodology was used. The purposive sample of 11 women who have given birth in the last year was applied. Their mean age was 27.6 years $(s=4.37)$; most of them $(n=5)$ finished upper secondary education; most of them $(n=7)$ were living in rural areas; more than half of the interviewees were primiparous women $(n=8)$. Data were collected using a semi-structured interview in January 2017. The data gathered were analyzed with the method of content analysis. Results: The analysis yield three themes, namely (1) the factors that affect the implementation, opportunities, motivation and awareness about the importance of physical activity during pregnancy, (2) the characteristics of performing physical activity in the postpartum period, (3) the implementation of pelvic floor muscle exercise during pregnancy and after childbirth. Discussion and conclusions: The results indicate that women are very aware about the importance of physical activity during pregnancy and its positive impact on childbirth, postpartum period, and psychological and physical well-being. The interviewees were the opinion that physical activity helped to facilitate childbirth and recovery after childbirth. The time taken by the individuals dedicated to physical activity differed between the interviewees. Most women during pregnancy were engaged in physical activity individually. They usually choose walking and swimming.

Key words: physical exercise, childbirth outcomes, pelvic floor muscle exercises, qualitative methodology 
$\mathrm{R}$

egular physical activity is one of the most important factors to lead of a healthy way of life. This also the case with the prenatal period, pregnanpected to be a part of everyday life of the future mother as long as there are no health or other complications associated with pregnancy. Physically fit and psychologically well prepared women bear their pregnancy better and are better prepared for the birth and also recover after it. A healthy lifestyle for pregnant women - including suitable sport activity as well as a healthy diet - have a positive impact on the growth and development of the fetus, are beneficial to the body and health, and also contribute to an easier childbirth and to get in shape faster after giving birth (Mlakar et al., 2011).

A lot of women want to change their physical activity the moment they find out they are pregnant. That is why it is important they get proper advice about doing physical activity during pregnancy. Some of them, especially in the first and last quarter of pregnancy do not have enough will and real energy for exercise while others are excessively concerned for the well-being and health of the fetus. A number of studies have shown that physical activity has beneficial effect on the mental stability of pregnant women, reduces lower back and other joints' pain, improves sleep, helps to maintain appropriate body weight, increases endurance and strength in labor (Larsson and Lindqvist, 2005), improves the cardio-vascular and respiratory system function, reduces the possibility of developing of pre-eclampsia, gestational diabetes and high blood pressure and it also helps to an easier childbirth and reduces the number of peripartal complications (Wadsworth, 2007; Lučovnik et al., 2013; Cid and Gonzalez, 2016). Pregnant women who are physically active have less pregnancy problems, less frequent pain in the pelvic ring and urinary incontinence (Videmšek et al., 2015).

\section{Methods}

We used a qualitative research paradigm. The test sample included eleven women who gave birth in the last year. Their average age was 27.6 years. The youngest was 22 years old and the oldest was 35 . Five of the participants had secondary education, two of them higher education, and four had a university degree. Most of them, i.e. seven participants, lived in rural areas, while four lived in the city. For one participant, it was her third childbirth, for two participants it was the second, and for eight it was their first. Regarding the gestational age, ten pregnancies were full-term and one was premature. In the participants who had a vaginal birth, the birth giving lasted 1 to 13 hours. On average, the childbirth lasted 7.3 hours in women giving birth for the first time, 4.5 hours in women giving birth for the second time, and only 1 hour in a woman giving birth for the third time.

The method of data collection was a semi-structured interview. We invited the potential participants to take part in the research in writing, with the explanation of the purposes and objectives of the research as well as its methods. 
We used contacts in our own social network, and with the technique of snowball sampling, we reached women who voluntarily accepted the invitation. According to their wishes and availability, we agreed on the date, place and time of the interview. The interviews were held in January and February 2017. We took into account the ethical aspects of the research, so all interviewees had to sign the informed consent form before the start of the interview in case they decided to participate. An introductory inquiry on sociodemographic data was followed by an interview which was sound recorded. The average interview lasted 30 minutes. The data obtained through the interview were analysed by content analysis of the text.

\section{Results}

After the initial coding phase of the text in which twenty-two categories were identified, they were combined into three central themes with individual subthemes that define physical activity during pregnancy. The themes were hierarchically distributed (Table 1), which means that the first topic was supported by most statements. And at least the statements of the women participating were the last topic.

Table 1: Themes in qualitative analysis.

\section{Theme}

\section{Subtopics}

The influence of the course of pregnancy on the physical activity during pregnancy

The factors that affect the implementation, opportunities, motivation and awareness about the importance of physical activity during pregnancy
Types and opportunities for physical activity before and during pregnancy

Accessing information, encouragement and motivation for physical activity during pregnancy

Awareness of the impact of physical activity on psychological and physical well-being

Physical activity in the postpartum period

The characteristics of performing phys

The gap between the awareness of the impact of pelvic floor muscle training and its realization
The implementation of pelvic floor muscle exercise during pregnancy and after childbirth.
95

24

\section{Discussion}

Results of the study showed that women are well informed about the importance of physical activity during pregnancy and are aware of its positive effects on their well-being, the course of pregnancy, the childbirth and the postpar- 
tum period. Through interviews and their answers gained, we found out that the interviewees did swimming, pilates, cycling on an exercise bike, skiing and hiking during pregnancy. Among the participants walking was dominating, because beside the already mentioned other types of physical activity, walking was chosen by all women. Most of them devoted between 30 and 60 minutes, some also more time, to physical activity depending on the day, their well-being and available time. On average, they were physically active five times a week. We believe that this is a good result according to the issued recommendations by American College of Obstetricians and Gynecologists (2002). The same can be confirmed by comparing this qualitative research with a quantitative study carried out by Rijavec (2016).

In the research, we found that all the interviewees were performing physical activity independently. It seems to us from a medical point of view, this information is worrying because we do not know whether the participants were familiar with it. What they need to be careful about doing and when they need to stop their physical activity. In any case, this could be the research question for a new research. Gogala (2013) found, that the majority of respondents, 39 (68.4\%), during their pregnancy used non-organized forms of physical activity, with their family and friends or independently. We also received interesting answers on the question where the women got information about the form or type of exercise to perform during the pregnancy. We were surprised by the statements of the participants that they found the information themselves using various easily accessible sources. At least ten participants confirmed that they had access to information via the Internet. We have a question here: »Is the Internet really a right, reliable source of information? « It is often believed that the answer is affirmative, but it is important to know on which website we access the information, otherwise, we could overlook important warnings. At this point, we have identified a gap, so we believe that greater awareness is needed, especially at the primary level of health care. Only three interviewees said in their statements that the information was provided by healthcare professionals. In a survey carried out by Gragelj (2014), 27 (54\%) of surveyed pregnant women received the most information about exercise during pregnancy on the Internet and only 6 pregnant women (12\%) from health workers at the parent's school..

Due to an important role of the pelvic floor muscles in the life of every woman, in this research, we tried to determine whether the participants were performing pelvic floor muscle training during pregnancy and whether they were aware of the importance of these muscles. The results show that all the women know the reasons for strengthening the pelvic floor muscles and are aware of how it can affect pregnancy, childbirth, and postnatal period. It was very encouraging to find that seven of them were doing pelvic floor muscle exercises already during the pregnancy. Rijavec (2016) reported that in her study, $35(76,1 \%)$ of the 46 women surveyed performed exercises for strengthening the pelvic floor muscles during pregnancy. 
The qualitative research confirmed the already known scientific findings: physical activity has beneficial effects on childbirth and postnatal recovery (Blenkuš et al., 2015; Videmšek et al., 2015) - which in this case, was also a subjective opinion of women. Participating women perceived physical activity to be important for an easier birth. Most of the interviewees believed that due to regular physical activity during the pregnancy, they had more power and physical fitness during the birth, which made their birth and the recovery period after that significantly easier and shorter.

The type of physical activity pregnant women can attend is organized exercise intended for them. In the results of the research we were surprised by the fact that only two women attended guided exercise during pregnancy but it was not specifically set for pregnant women.

In a study conducted by Rijavec (2016), only 9 (19.6\%) of the 46 respondents decided on organized group exercise during pregnancy. In a study conducted by Husić (2015) this type of activity was attended by 6 (15.8\%) of the 40 respondents. According to the results of these studies, we can conclude that in general, women are generally less likely to have guided exercise in pregnancy. The finding that there is not an organized physical exercise for participating pregnant women in their hometown or in their immediate area is a concern. We believe that in the future organized exercise intended for pregnant women should expand and take place in all health centers throughout Slovenia. In Slovenia we have not come across any qualitative research in this field, so we believe that in the future it would be necessary to carry out a similar, more extensive survey that would allow comparison of results and would thus show the difference between the physical activity of the pregnant women that live in rural areas and those who live in the urban environment.

\section{Conclusions}

Modern women are very aware of the importance of regular physical activity (especially during pregnancy) and all its positive impacts on psychological and physical well-being, the course of pregnancy, childbirth and postpartum period. They also know that a fit woman will quickly adapt to all the changes that happen in her new period.

Physical activity during pregnancy is definitely one of the most important factors affecting the mental and physical well-being of the mother-to-be, the course of pregnancy, childbirth and postpartum period. All participants showed that with their statements. They were physically active before pregnancy and even more committed to and continued it over their expecting period. A detailed analysis of the results has confirmed the fact that health-care workers have known for a long time - physical activity positively affects the well-being of the pregnant women and their health and the fact that pregnant women who take regular exercise feel better. There has been less tension in them. In this emotionally delicate period they were more relaxed, had more strength 
and energy, and were physically better prepared for childbirth. All of this has consequently led to an easier delivery and faster recovery afterwards.

\section{References}

American College of Obstetricians and Gynecologists, 2002. Exercise during pregnancy and the postpartum period: ACOG Committe Opinion No. 267: Obstetrics \& Gynecology, vol. 99, no. 1, pp. 171-173.

BLENKUŠ, Š., ČEMAŽAR, V., VIDEMŠEK, M., HADŽIĆ, V., PIRKMAJER, S. and ROTOVNIK-KOZJEK, N., 2015. Pomen telesne dejavnosti v nosečnosti. In: NOVAK-ANTOLIČ, Ž., KOGOVŠEK, K., ROTOVNIK-KOZJEK, N. and MLAKAR-MASTNAK, D., eds. Klinična prehrana v nosečnosti. Ljubljana: Center za razvoj poučevanja, Medicinska fakulteta, Univerza v Ljubljani, pp. 145-160.

CID, M., and GONZALEZ, M., 2016. Potential benefits of physical activity during pregnancy for the reduction of gestational diabetes prevalence and oxidative stress [online]. Early Human Development, vol. 94, pp. 57-62. [viewed 16. 11. 2016]. Available from: http://www.sciencedirect.com/science/article/pii/So37837821600oo62

GOGALA, E., 2013. Počutje nosečnic glede na njihovo športno aktivnost: diploma thesis [online]. Ljubljana: Univerza v Ljubljani, Fakulteta za šport, pp. 18, 21. [viewed 9. 7. 2017]. Available from: https://www.fsp.uni-lj.si/cobiss/ diplome/Diploma22070140GogalaEva.pdf

GREGELJ, I., 2014. Telesna aktivnost med nosečnostjo: diploma thesis [online]. Murska Sobota: Evropski center Maribor, pp. 38. [viewed 10. 7. 2017] . Available from: http://www.mss.si/datoteke/dokumenti/diplomske/2014/ gregelj_diplomska.pdf

HUSIĆ, T., 2015. Telesna vadba v nosečnosti: diploma thesis [online]. Maribor: Univerza v Mariboru, Pedagoška fakulteta, Oddelek za predšolsko vzgojo, pp. 35, 37, 40, 41. [viewed 7. 6. 2017]. Available from https://dk.um. si $/$ Iskanje.php? type $=$ napredno\&lang $=$ slv\&stlo $=$ Avtor $\&$ nizo $=$ Tama $\mathrm{ra}+\mathrm{Husi} \% \mathrm{C}_{4} \% 87$

LARSSON, L., and LINDQVIST, P.G., 2005. Low-impact exercise during pregnancy - a study of safety [online]. Acta Obstetricia et Gynecologica Scandinavica, vol. 84, no. 1, pp. 34-38. [viewed 16. 11. 2015]. Available from: http:// onlinelibrary.wiley.com/wol1/doi/10.1111/j.0oo1-6349.2005.00696.x/full

LINDQVIST, M., LINDKVIST, M., EURENIUS E., PERSSON, M., IVARSSON, A., and MOGREN, I., 2016. Leisure time physical activity among pregnant women and its associations with maternal characteristics and pregnancy outcomes [online]. Sexual \& Reproductive Healthcare, vol. 2016, no. 9, pp. 14-20. [viewed 11. 1. 2017]. Availabne from http://www.srhcjournal.org/article/S1877-5756(16)30026-X/pdf 
LUČOVNIK, M., BLICKSTEIN, I., STEBLOVNIK; L., VERDENIK, I., TROJNER BREGAR, A., and TUL, N., 2013. Vpliv debelosti pred zanositvijo in prekomernega prirasta telesne teže $\mathrm{v}$ nosečnosti na izid nosečnosti. Ljubljana: Zbornica zdravstvene in babiške nege, Sekcija medicinskih sester in babic, pp. 29-37.

MLAKAR, K., VIDEMŠEK, M., VRTAČNIK-BOKAL, E., ŽGUR, L. and ŠĆEPANOVIĆ, D., 2011. Z gibanjem $v$ zdravo nosečnost. Ljubljana: Univerza v Ljubljani, Fakulteta za šport, pp. 7 and 20.

RIJAVEC, A., 2016. Telesna aktivnost med nosečnostjo: diploma thesis. Izola: Univerza na Primorskem, Fakulteta za vede o zdravju, pp. 26-31.

VIDEMŠEK, M., BOKAL-VRTAČNIK, E., ŠĆEPANOVIĆ, D., ŽGUR, L., VIDEMŠEK, N., MEŠKO, M., KARPLJUK, D., ŠTIHEC, J. in HADŽIĆ, V., 2015. Priporočila za telesno dejavnost nosečnic. Zdravniški vestnik, vol. 84, no. 2, pp. 87-98.

WADSWORTH, P., 2007. The benefits of exercise in pregnancy [online]. American College of Nurse Practitioners, vol. 3, no. 5, pp. 333-339. [viewed 16. 11. 2016]. Available from: http://www.sciencedirect.com/science/article/pii/ S1555415507002127 